$\xi=$ 圆

\title{
A Case Study of Health Expenditure in India
}

\author{
D. Kalpanapriya, M.Mubashir Unnissa", Rakshanya Sekar \\ VIT, Vellore-632 014, INDIA. \\ *Corresponding author E-mail: mubashira@vit.ac.in,
}

\begin{abstract}
The article aims in analysing healthcare expenditure of India, as it struggles to meet the health care requirements of all the citizens. In order to acheieve this, it is important to understand the trends in healthcare expenditure of the country to create a sustainable health expenditue model. Post millenium, with various reforms and increased awareness, a certain redistribution can be observed among different arms that contribute to total healthcare expenditure. This study reviews and summarise the expenditure trends between the years 2004 and 2014. Numerical illustrtions are also provided to show the government and private sectors contributions on the health care products.
\end{abstract}

Keywords: Health care expenditure, Correlation, Regression, Government, Private sector

\section{Introduction}

Statistics is basically a mathematical science which includes collection of data, analysing the data and to make necessary calculations on them so that meaningful conclusions can be made out from the data. Statistics is having a major boom in modern days and also has a wide range of applications in the world. Statistics is of two types: descriptive statistics a method of collecting organising and presenting the data while inferential statistics is to draw conclusions on the population based on the sample. In real scenario, statistics deals with data collection. A data collection is processes of collecting the relevant information from various sources to perform necessary calculations in order to interpret the results of the analysed data. Broad classification of the data based on quantitative and qualitative analysis. Further, two types of data collections are primary data and secondary data collection, while former is collected to perform desired analysis while later is already complied and ready for the data analysis.(Refer [8-9]).

Regression and correlation analysis is basically a major aspect of statistics which transferred statistics into a rigorous mathematical discipline used for analysis not just in science but in industry, politics, medical science, social science and many more areas. Regression attempts to determine the strength of the relationship between one dependent variable with respect to other changing variables which are often referred to as independent variables. (Refer [1-2], [4], [6-7]). In this article a secondary data collection is carried out to perform a particular case study in India for the period of 2004 to 2014 on health care expenditure to analyse its effect using various statistical tools.

\section{Health Care Systems}

A year 2000 report of world health organisation ranks India 112 out of 190 countries in health care systems. Despite being a fast developing country with strong agendas, the country spends only close to $4.69 \%$ of it's national GDP towards healthcare goods and services ( Refer [3], [5], [9], [10]). Furthermore there is a wide gaps between the rural and urban populations in the country's healthcare system which is to bridged in order to take giant leaps towards a better healthcare system for the 1.324 billion population. Around seventy percent of the populaton in India lives in rural areas where there is very few opportunity to obtain a private heath care which in turn refelcts the spending is less than 30 percent of total expenditure on health care. In order to bridge the gap between rural and urban areas its very crucial to understand the the countries health expenditure between govenrment and private sector.

Majority of paitients in India bear their hospital expenditure on their own, there are no external funding agencies to support the individuals in health care systems. This has to be rectified by the introduction of more health care scemes to the individuals by the central government providing subsidies and insurance in most health expenses. The percentage of GDP spent on health expenditure is high in the developed countries., Azerbaijan has lowest percent spent on GDP while USA spends 17.8 percent. Recently, authorisation of National Health Policy central government has promised to increase their contributions to $2.5 \%$ of the country's GDP. It is essential to understand the pattern of private, government and other sectors which contribute to the health expenditure of the nation. The idea of this study is to review the health expenditure of India in the prsent scenario and to improve the health expenditure of the country incorporating the new measures. Table 1 depicts the data obtained from world health organisation on India's health expenditure during the years 2004 to 2014. It is clearly visible that the total expenditure on health has been incresing in particular the government expenditure and indiviual spending while the private sectors there is a decrease on health expenditure

The government, especially in a large country like India (Refer Fig.1), cannot look after the health of its people in its entirety.There has to be certain basic agedas and planning as to how the available funds are put to best use for the citizen's healthcare.The role of government and the private initiatives is to be clearly defined, so that the efforts are complimentary. Indian private sector of healthcare contributes close to 70 percent of the total health expenditure (as on 2004) and this percentage has 
decreased by 5 percent from 2014.(Refer Fig.2 and Fig.3) This is a marker for not just increased public health care funding but also other means of International funding, NGO, Inter- Rural, InterUrban state funds etc. Fig. 4 and Fig. 5 shows the pattern of contribution of various sectors towards health expenditure through Pie charts. It is observed that the contribution from the local bodies has been decreased while there is increase in contributions from the state, central government and other sectors while there is no change in local bodies.

\begin{tabular}{|c|c|c|c|c|c|c|c|c|}
\hline Country & $\begin{array}{r}\text { Data } \\
\text { Source }\end{array}$ & Year & $\begin{array}{c}\text { Total } \\
\text { expenditure } \\
\text { on health as } \\
\text { a } \\
\text { percentage } \\
\text { of gross } \\
\text { domestic } \\
\text { product }\end{array}$ & $\begin{array}{c}\text { General } \\
\text { government } \\
\text { oxpenditure on } \\
\text { health as a } \\
\text { percentage of } \\
\text { total } \\
\text { expenditure on } \\
\text { health' }\end{array}$ & $\begin{array}{l}\text { Private } \\
\text { expenditure } \\
\text { on health as } \\
\text { a percentage } \\
\text { of total } \\
\text { expenditure } \\
\text { on health' }\end{array}$ & $\begin{array}{c}\text { General } \\
\text { government } \\
\text { expenditure on } \\
\text { health as a } \\
\text { percentage of } \\
\text { total government } \\
\text { expenditure' }\end{array}$ & $\begin{array}{c}\text { Out-of-pocket } \\
\text { expenditure } \\
\text { as a } \\
\text { percentage of } \\
\text { private } \\
\text { expenditure } \\
\text { on health' }\end{array}$ & $\begin{array}{l}\text { Out-ot- } \\
\text { pocket } \\
\text { expenditure } \\
\text { as a } \\
\text { percentage } \\
\text { of total } \\
\text { expenditure } \\
\text { on healthi }\end{array}$ \\
\hline \multirow{11}{*}{ India } & \multirow{11}{*}{$\begin{array}{l}\text { India } \\
\text { note' }\end{array}$} & 2014 & 4.69 & 30.04 & 69.96 & 5.05 & 89.21 & 62.42 \\
\hline & & 2013 & 4.53 & 28.41 & 71.59 & 4.66 & 89.14 & 63.81 \\
\hline & & 2012 & 4.39 & 26.97 & 73.03 & 4.49 & 88.85 & 64.88 \\
\hline & & 2011 & 4.33 & 27,14 & 72.86 & 4.42 & 88.43 & 6443 \\
\hline & & 2010 & 4.28 & 27.13 & 72.87 & 4.29 & 86.96 & 63.37 \\
\hline & & 2009 & 4.38 & 27.90 & 72.10 & 4.37 & 87.84 & 63.33 \\
\hline & & 2008 & 4.34 & 26.79 & 73.21 & 4.34 & 87.96 & 6438 \\
\hline & & 2007 & 423 & 26.02 & 73.98 & 4.43 & 8820 & 65.25 \\
\hline & & 2006 & 4.26 & 26.15 & 73,85 & 4.40 & 89.03 & 66.76 \\
\hline & & 2005 & 4.28 & 26.49 & 73.51 & 4.51 & 89.65 & 65.90 \\
\hline & & 2004 & 4.22 & 24.23 & 75.77 & 4.04 & 89.55 & 67.85 \\
\hline
\end{tabular}

INDIA POPULATION

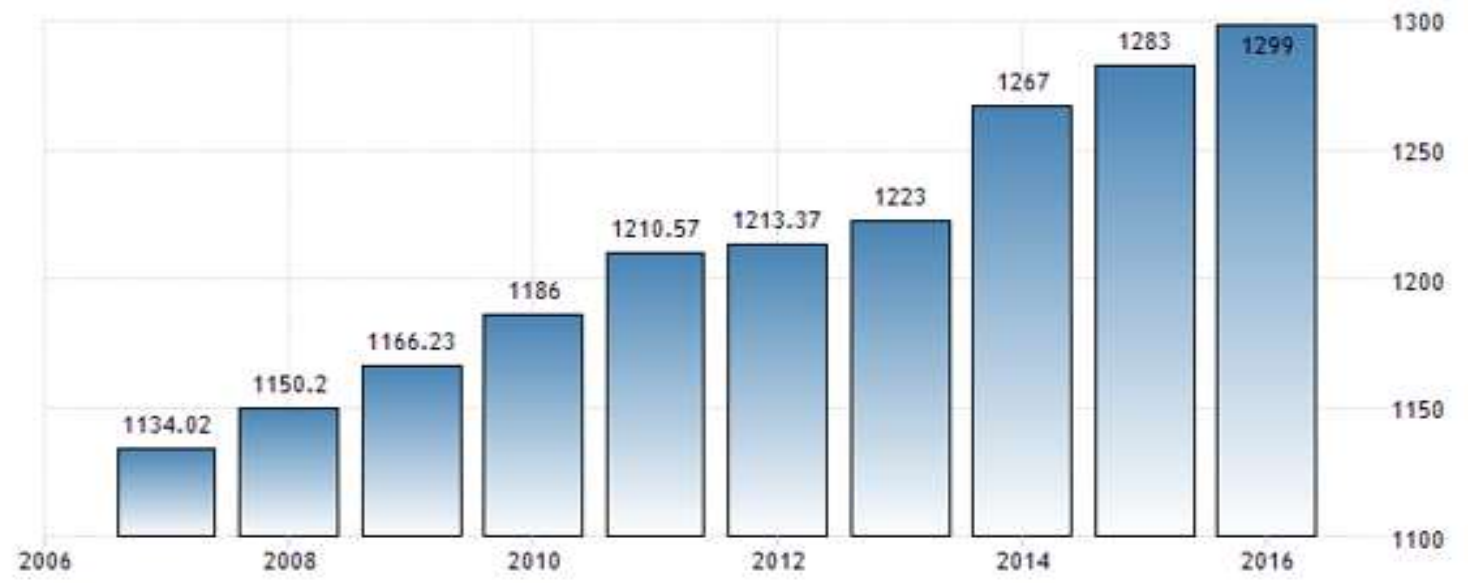

Fig. 1: India population increase between 2006 and 2016

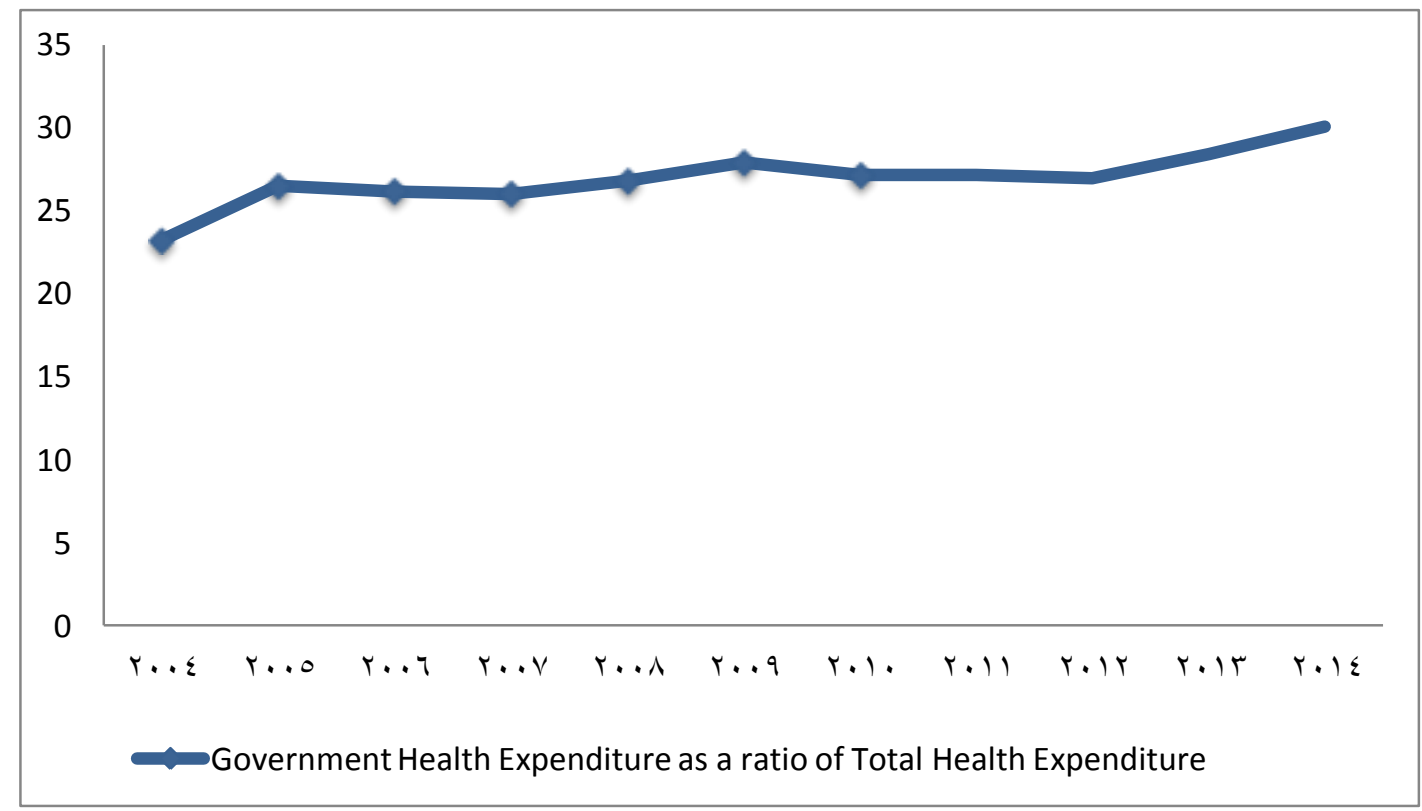

Fig. 2: Comparative ratios of government health expenditure and total health expenditure 


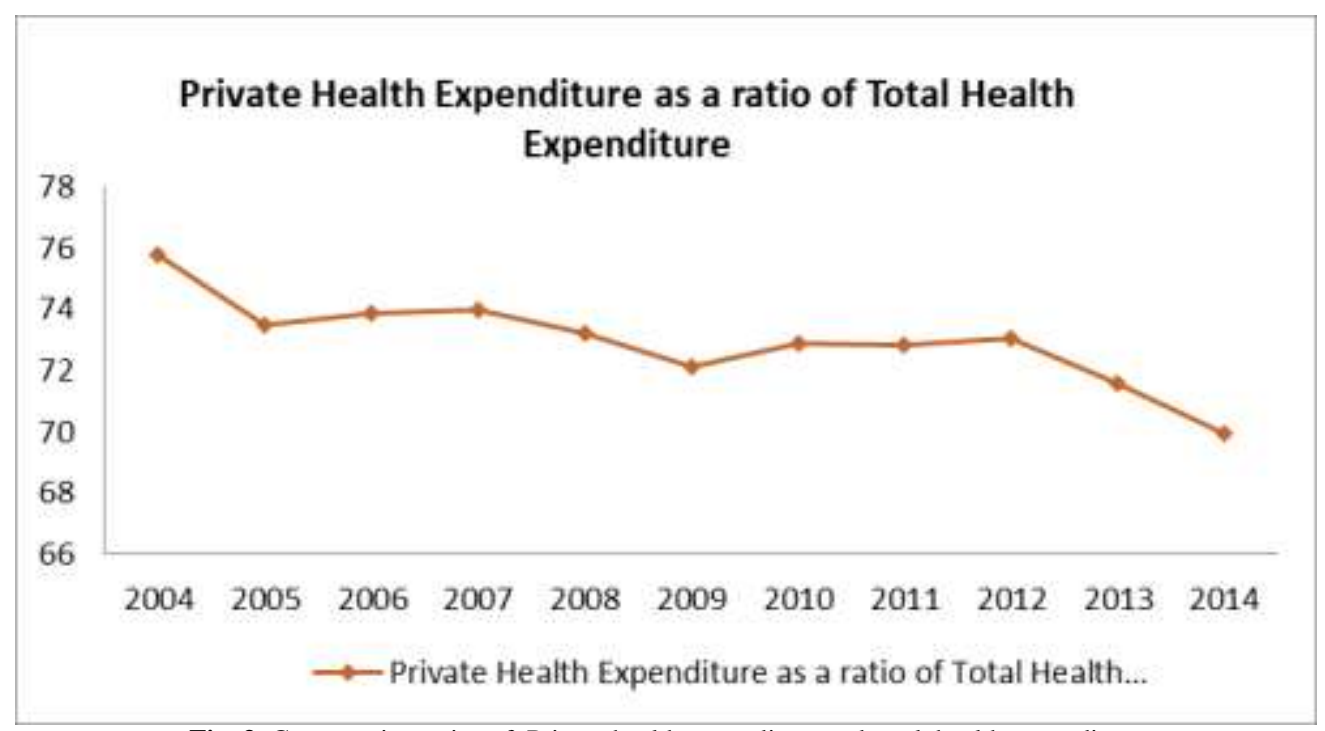

Fig. 3: Comparative ratios of Private health expenditure and total health expenditure

\section{= Household $=$ State Government $=$ Central Government $=$ Local Bodies $=$ Others}

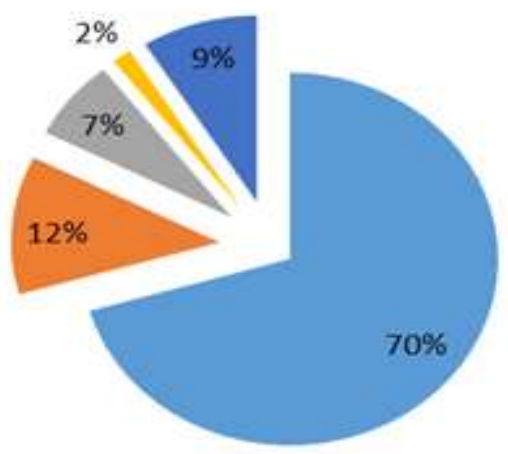

Fig. 4: Contributions of government and private sectors in 2004

\section{Household $\quad$ State Government $\quad$ Central Government $\quad$ Local Bodies $\quad$ Others}

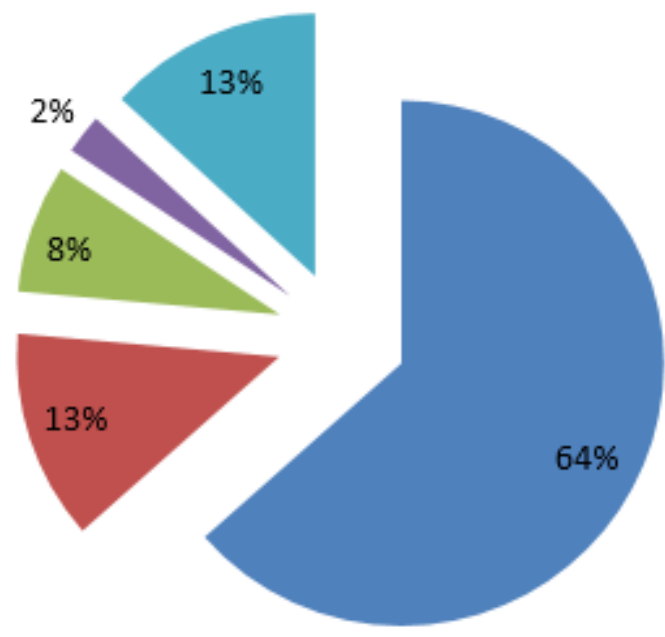

Fig. 5: Contributions of government and private sectors in 2004

\section{Numerical Illustrations}

A numerical illustration is carried out using correlation and linear regression analysis to discuss the comparative analysis of the health expenditure by government and private sectors so as to fill the gap between the rural and urban areas. The data is obtianed from the Table 1 is used to find the correlation between the govenrment and the private sector and the value is -1 which prdicts that both the government and private sector contributes in the developmen of health care expenditure in order to bridge between the rural and urban sectors.(refer Fig. 6). Furthermore when regression analysis is carried the two variables form a perfect fit as the squared value is one. The government and private 
sectors are linearly depented. Thus the regression analysis suggests, as out of pocket expenditure (individual expenditure) is one of the prime parts of Private expenditure, Increasing Government Expenditure on Public health even by small percentages in a pro- longed time period will decrease the direct out of pocket spending. This will prove beneficial especially for people belonging to the rural areas where private healthcare facilities are scarcely available or not accessible.

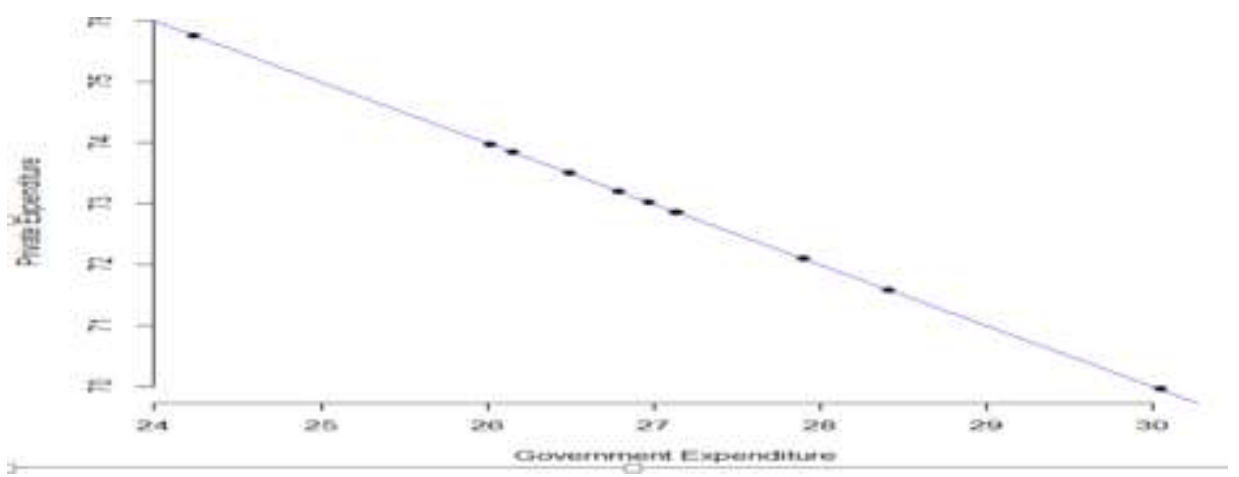

Fig. 6: Correlation between government and private sectors

\section{Conclusion}

India with its staggering population of 1.32 billion cannot meet all the health expenditure of its citizens. Sixty five percent of nation's population are below the age thirty five must be assured of healthcare benefits. This article surveyed the India's health expenditure between 2004 to 2014 to predict the contributions of government and private sector on health care units. It is to be concluded that both the private and the government sectors have improved in the health care expenditure to fill the gap between the rural and urban areas.

\section{References}

[1] Alaimo K, Olson CM, and Frongillo EA (2001) Food insufficiency and American school-aged children's cognitive, academic, and psychosocial development, Pediatrics, 108, 44-53.

[2] Arum R (1998) The effects of resources on vocational student educational outcomes: Invested dollars or diverted dreams? Sociology of Education, 71, 130-151.

[3] Data, The world bank (IBRD - IDA) https://data.worldbank.org/

[4] Harrell F. Regression modeling strategies: with applications to linear models, logistic regression, and survival analysis, New York, NY: Springer-Verlag, (2001).

[5] Indian Brand Equity foundation- Healthcare data tools https://www.ibef.org

[6] Kleinbaum DG, Kupper LL, Muller KE, Nizam A. Applied regression analysis and multivariable methods, Pacific Grove, CA: Duxbury Press (1998)

[7] Kleinbaum DG. Logistic regression: a self-learning text, 2nd ed. New York, NY: Springer-Verlag (2002).

[8] Liu BYH, Jordan, RC, (1960), The interrelationship and characteristic distribution of direct, diffuse and total solar radiation. Sol. Energy 4, 1-19.

[9] Trading economics: ministry of statistics and program implementation, www.mospi.gov.in

[10] WHO data bank for health expenditure India 2004-2014 https://mohfw.gov.in/sites 